\title{
Effect of Diet Composition on Excreta Composition and Ammonia Emissions from Growing-Finishing Pigs
}

\author{
Phung Le Dinh ${ }^{1,2}$, Carola M. C. van der Peet-Schwering ${ }^{1}$, Nico W. M. Ogink ${ }^{1}$ and André J. A. Aarnink ${ }^{1, * *(1)}$ \\ 1 Wageningen Livestock Research, Wageningen University and Research, \\ 6708 WD Wageningen, The Netherlands; ldphung@hueuni.edu.vn (P.L.D.); gvdpeet@wxs.nl (C.M.C.v.d.P.-S.); \\ nico.ogink@wur.nl (N.W.M.O.) \\ 2 Faculty of Animal Sciences and Veterinary Medicine, University of Agriculture and Forestry, Hue University, \\ 102 Phung Hung, Hue, Vietnam \\ * Correspondence: andre.aarnink@wur.nl; Tel.: +31-317-480191
}

check for updates

Citation: Le Dinh, P.; van der Peet-Schwering, C.M.C.; Ogink, N.W.M.; Aarnink, A.J.A. Effect of Diet Composition on Excreta Composition and Ammonia Emissions from Growing-Finishing Pigs. Animals 2022, 12, 229. https:// doi.org/10.3390/ani12030229

Academic Editor: Martina Pérez Serrano

Received: 12 November 2021

Accepted: 12 January 2022

Published: 18 January 2022

Corrected: 1 April 2022

Publisher's Note: MDPI stays neutral with regard to jurisdictional claims in published maps and institutional affiliations.

Copyright: (C) 2022 by the authors. Licensee MDPI, Basel, Switzerland. This article is an open access article distributed under the terms and conditions of the Creative Commons Attribution (CC BY) license (https:// creativecommons.org/licenses/by/ $4.0 /)$.
Simple Summary: Pig production leads to high levels of ammonia emissions, which in turn causes environmental pollution. This paper, therefore, looks at the possibilities for reducing ammonia emissions. Reducing ammonia precursors in diets and acidifying the urine and manure $\mathrm{pH}$ by acidifying diets make it possible to reduce the ammonia emissions from pig production facilities. The present study tested the impact of decreased crude protein or acidifying diets on urine and manure composition and ammonia emissions from growing and finishing pig houses. We found that decreasing dietary crude protein levels reduced the ammonia emissions from the floor as well as from the pig houses, whereas acidifying diets failed to reduce ammonia emissions from the floor and the pig houses. Reducing dietary crude protein is, therefore, a positive solution to reduce ammonia emissions from pig houses.

\begin{abstract}
This study aimed to investigate the impact of decreased crude protein (CP) levels (by $2 \%$ units) or acidifying diets (by adding $10 \mathrm{~g}$ benzoic acid $/ \mathrm{kg}$ diet in combination with replacing a part of $\mathrm{CaCO}_{3}$ by about $10 \mathrm{~g}$ Ca-formate $/ \mathrm{kg}$ diet) on urine, feces and manure composition and ammonia emissions from growing and finishing pig houses. Yorkshire $x$ F1(Landrace $x$ Yorkshire) pigs $(\mathrm{n}=576)$ with an initial body weight of $24.9 \pm 3.4 \mathrm{~kg}$ were randomly allocated to four treatments of (i) a control diet with normal protein content and no acidifying components added; (ii) a diet with $2 \%$ units $\mathrm{CP}$ reduction; (iii) a diet with an acidifying effect on the manure; (iv) or a diet consisting of a combination of diet (ii) and (iii). Pigs were housed in four mechanically ventilated and temperature-controlled rooms. Results showed that decreasing the dietary CP levels by $2 \%$ units reduced the ammonia emission from the floor by $46 \%(p=0.06)$ and from the pig house by $31 \%(p=0.08)$. Decreased CP diets reduced the total $\mathrm{N}$ in feces and in manure and $\mathrm{NH}_{4}-\mathrm{N}$ in the manure, as well as the ammonia concentration at $1 \mathrm{~cm}$ and $10 \mathrm{~cm}$ above the manure surface $(p<0.05)$. However, acidifying diets failed to reduce ammonia emissions from the floor and the pig house $(p>0.05)$. Reducing dietary crude protein is, therefore, a solution to reducing ammonia emissions from pig houses.
\end{abstract}

Keywords: dietary manipulation; ammonia emission; excreta composition; growing and finishing pigs

\section{Introduction}

Ammonia is an important pollutant gas that accelerates fine particulate formation in the atmosphere and plays a crucial role in the acidification and eutrophication of ecosystems [1]. In addition, ammonia is a well-known toxic gas that can irritate the respiratory tract at concentrations exceeding 15 ppm [2]. Livestock waste accounts for $39 \%$ of global $\mathrm{NH}_{3}$ emissions [3]. In Europe, approximately $80 \%$ of $\mathrm{NH}_{3}$ production originates from livestock facilities [4]. Pig production is globally responsible for about $15 \%$ of $\mathrm{NH}_{3}$ emissions 
associated with livestock [5]. In Europe, pig production represents nearly 25\% of livestock ammonia emissions [6]. Ammonia released from buildings is the main source, accounting for about $50 \%$ of pig $\mathrm{NH}_{3}[7,8]$. Therefore, ammonia emission from pig production facilities should be reduced.

In livestock production, the main source of $\mathrm{NH}_{3}$ is the rapid hydrolyzation of urea in urine by the fecal enzyme urease, which leads to ammonium formation in an aqueous medium [9]. Another minor source of ammonia is the degradation of undigested proteins in manure. In the liquid phase, total ammoniacal $\mathrm{N}$ is in a state of equilibrium between ionized $\mathrm{NH}_{4}{ }^{+}$and unionized $\mathrm{NH}_{3}$. This equilibrium is influenced by temperature and $\mathrm{pH}$. Higher temperature and $\mathrm{pH}$ enhance $\mathrm{NH}_{3}$ concentration. At $\mathrm{pH}$ values below 7, nearly all ammoniacal $\mathrm{N}$ is in its ionized form. At $\mathrm{pH}$ above 7 , the unionized fraction increases significantly.

Dietary nitrogen is the main precursor of ammonia production from pig production facilities. This ammonia emission depends on many factors, e.g., animal housing (floor type, ambient temperature and ventilation), animal (animal physiological stage, genotype/line and gender), diet (dietary crude protein, fiber type and level, feed additives such as acidifying salts and electrolyte balance), feeding management (feeding level, phase feeding), the drinking system and the manure removal system.

Feed and feeding manipulation have been shown to be effective measures for reducing ammonia emissions from pig production facilities. Reducing dietary crude protein (CP) or acidifying diets have been studied for their capacity to reduce ammonia emissions [10]. However, in most studies, ammonia emissions were measured in vitro or measured above the manure pit. The objective of this study is to study the impact of dietary measures, including reduced dietary crude protein level or acidifying salt supplementation on ammonia emissions from pig houses, urine and manure compositions.

\section{Materials and Methods}

The Animal Welfare Body of Wageningen Research, the Netherlands (IvD_WR) considered that this type of research did not fall under the legislation for the protection of animals used for scientific purposes, national decree-law 113/2013 (2010-63-EU directive). Therefore, this research got approval for ethical exemption.

\subsection{Animals, Experimental Design, Diets and Housing}

A total of 576 Yorkshire $x$ F1 (Landrace $x$ Yorkshire) pigs with an initial body weight of $24.9 \pm 3.4 \mathrm{~kg}$ (mean \pm standard deviation) at $63.3 \pm 3.0$ days old were randomly allocated into four treatments of (i) a control diet (CON) with normal protein content and no acidifying components added; (ii) a diet with a $2 \%$ reduced protein content (RDP); (iii) a diet with an acidifying effect (AD) on the manure; (iv) and a diet consisting of a combination (CD) of diet (ii) and (iii). Acidifying diets were achieved by adding benzoic acid $(10 \mathrm{~g} / \mathrm{kg})$ in combination with replacing a part of the $\mathrm{CaCO}_{3}$ by approximately $10 \mathrm{~g}$ Ca-formate per $1 \mathrm{~kg}$ of the diet (on a Ca-equivalent basis).

The experiment lasted for 110 days. Pigs were fed a starter diet for five weeks, a grower diet for four weeks, and a finisher diet for seven weeks. Diets were formulated to have similar contents of net energy, dietary electrolyte balance, crude fiber and non-starch polysaccharides but differed in crude protein levels, benzoic acid and Ca-formate contents (Tables 1 and 2). All diets were supplemented with synthetic Lysine (Lys), Methionine (Met), Tryptophan (Trp) and Threonine (Thr) up to the level of the animals' requirement [11] based on apparent ileal amino acid digestibility (Table 1). 
Table 1. Ingredient composition of experimental diets, as-fed basis.

\begin{tabular}{|c|c|c|c|c|c|c|c|c|c|c|c|c|}
\hline \multirow[t]{2}{*}{ Composition (\%) } & \multicolumn{4}{|c|}{ Starter Diet } & \multicolumn{4}{|c|}{ Grower Diet } & \multicolumn{4}{|c|}{ Finisher Diet } \\
\hline & CON & RCP & $\mathrm{AD}$ & CD & CON & RCP & AD & CD & CON & RCP & AD & CD \\
\hline Maize & 11.32 & 12.81 & 11.79 & 12.81 & 5.40 & 5.00 & 5.00 & 5.00 & 5.00 & 5.00 & 5.40 & 5.00 \\
\hline Barley & 24.63 & 24.63 & 24.63 & 24.63 & 19.80 & 22.70 & 19.80 & 22.00 & 19.80 & 19.80 & 19.80 & 19.80 \\
\hline Wheat & 17.50 & 16.75 & 14.78 & 16.75 & 27.45 & 26.80 & 25.07 & 24.80 & 27.65 & 29.64 & 24.56 & 28.74 \\
\hline Maize feed meal & 5.00 & 4.81 & 5.00 & 4.41 & 4.50 & 4.95 & 4.75 & 4.95 & 4.50 & 4.95 & 4.50 & 4.95 \\
\hline Wheat middlings & & 3.39 & 1.01 & 4.21 & 7.00 & 9.90 & 7.00 & 9.90 & 7.00 & 10.00 & 7.00 & 10.00 \\
\hline Biscuits, ground & 4.93 & 4.38 & 4.93 & 3.94 & 4.30 & 4.00 & 5.00 & 5.00 & 3.50 & 2.80 & 4.50 & 3.00 \\
\hline Wheat gluten feed meal & 7.30 & 6.90 & 7.22 & 6.90 & 5.00 & 5.00 & 5.00 & 5.00 & 4.50 & 4.50 & 4.50 & 4.90 \\
\hline Vegetable oil & 1.61 & 1.92 & 1.82 & 1.90 & 1.50 & 1.60 & 1.95 & 2.00 & 1.00 & 1.00 & 1.40 & 1.35 \\
\hline Potato protein & & 0.28 & & & & & & & & & & \\
\hline Sugar beet pulp & & & & & 1.10 & 1.30 & 1.10 & 1.30 & 1.10 & 1.50 & 1.10 & 1.20 \\
\hline Soybean meal HIPRO & 17.29 & 14.87 & 17.77 & 16.04 & 10.10 & 7.90 & 11.00 & 8.30 & 8.50 & 5.00 & 9.00 & 5.00 \\
\hline Soybean hulls & & 1.04 & & 0.77 & 1.30 & 2.00 & 1.30 & 2.00 & 1.00 & 1.00 & 1.00 & 1.00 \\
\hline Rapeseed meal, fat extract & 4.93 & & 4.93 & & 5.00 & & 5.00 & & 4.80 & 1.00 & 5.00 & 1.10 \\
\hline Sunflower seed meal, fat extract & 1.48 & 0.99 & 1.21 & & 4.00 & 2.90 & 3.20 & 3.00 & 3.50 & 3.50 & 3.50 & 3.60 \\
\hline Palm kernel flakes & & & & & & & & & 4.40 & 4.90 & 3.80 & 5.00 \\
\hline Whey, concentrated & 0.40 & 3.00 & 0.10 & 2.07 & 1.10 & 3.00 & 1.10 & 2.80 & 1.70 & 3.00 & 1.70 & 1.70 \\
\hline Limestone & 1.14 & 1.11 & 0.30 & 0.30 & 0.89 & 0.89 & & & 0.93 & 0.96 & 0.13 & 0.18 \\
\hline Salt & 0.28 & 0.20 & 0.29 & 0.21 & 0.20 & 0.22 & 0.20 & 0.12 & 0.19 & 0.09 & 0.19 & 0.08 \\
\hline Vitamin extra & & & & & 0.19 & 0.19 & 0.19 & 0.19 & & & & \\
\hline Premix ${ }^{1}$ & 0.25 & 0.25 & 0.25 & 0.25 & 0.26 & 0.26 & 0.26 & 0.26 & 0.25 & 0.25 & 0.25 & 0.25 \\
\hline DL-Methionine & 0.09 & 0.17 & 0.10 & 0.21 & 0.03 & 0.08 & 0.03 & 0.08 & & 0.03 & & \\
\hline L-Lysine HCL & 0.52 & 0.71 & 0.50 & 0.70 & 0.41 & 0.61 & 0.38 & 0.60 & 0.29 & 0.51 & 0.28 & 0.51 \\
\hline L-Threonine & 0.14 & 0.22 & 0.14 & 0.22 & 0.09 & 0.17 & 0.09 & 0.17 & 0.04 & 0.12 & 0.04 & 0.12 \\
\hline L-Tryptophan & 0.05 & 0.17 & 0.05 & 0.16 & & 0.09 & & 0.08 & & & & \\
\hline Valine & & 0.29 & & 0.30 & & & & & & & & \\
\hline Benzoic acid & & & 1.00 & 1.00 & & & 1.00 & 1.00 & & & 1.00 & 1.00 \\
\hline Calcium formate & & & 1.04 & 1.03 & & & 1.00 & 1.00 & & & 1.00 & 1.00 \\
\hline
\end{tabular}

$\mathrm{CON}=$ control diet, $\mathrm{RDP}=$ reduced crude protein diet, $\mathrm{AD}=$ acidifying diet, $\mathrm{CD}=$ combined diet $=$ reduced crude protein + acidifying diet. ${ }^{1}$ The vitamin-mineral premix supplied per kg feed included $7000 \mathrm{IU}$ vitamin A, $1700 \mathrm{IU}$ vitamin D3, 20 IU vitamin E, $1.5 \mathrm{mg}$ vitamin $\mathrm{K}, 1.5 \mathrm{mg}$ vitamin B1, $4 \mathrm{mg}$ vitamin B2, $11 \mathrm{mg}$ d-pantothenic acid, $18 \mathrm{mg}$ niacine, $18 \mu \mathrm{g}$ vitamin B12, $0.1 \mathrm{mg}$ folium acid, $1.0 \mathrm{mg}$ vitamin B6, $100 \mathrm{mg}$ choline chloride, $75 \mathrm{mg} \mathrm{Fe}, 10 \mathrm{mg}$ $\mathrm{Cu}, 65 \mathrm{mg}$ Zn, $30 \mathrm{mg} \mathrm{Mn,} 0.15 \mathrm{mg} \mathrm{Co,} 0.75 \mathrm{mg} \mathrm{I}, 0.30 \mathrm{mg}$ Se.

Table 2. Nutrient compositions of experimental diets, as fed basis.

\begin{tabular}{|c|c|c|c|c|c|c|c|c|c|c|c|c|c|}
\hline \multirow[b]{2}{*}{ Composition } & \multirow[b]{2}{*}{ Unit } & \multicolumn{4}{|c|}{ Starter Diet } & \multicolumn{4}{|c|}{ Grower Diet } & \multicolumn{4}{|c|}{ Finisher Diet } \\
\hline & & $\mathrm{CON}$ & RCP & AD & CD & $\mathrm{CON}$ & RCP & AD & CD & $\mathrm{CON}$ & RCP & AD & $\mathrm{CD}$ \\
\hline \multicolumn{14}{|l|}{ Calculated composition } \\
\hline Crude protein & $\%$ & 18.50 & 16.50 & 18.50 & 16.50 & 16.03 & 14.00 & 16.03 & 14.02 & 15.52 & 13.52 & 15.52 & 13.50 \\
\hline Crude fat & $\%$ & 4.37 & 4.63 & 4.59 & 4.57 & 4.21 & 4.24 & 4.70 & 4.71 & 3.86 & 3.82 & 4.29 & 4.20 \\
\hline Crude fiber & $\%$ & 4.20 & 4.04 & 4.20 & 3.84 & 5.85 & 5.48 & 5.64 & 5.49 & 6.21 & 6.05 & 6.13 & 6.08 \\
\hline Crude ash & $\%$ & 5.00 & 4.95 & 4.99 & 4.92 & 4.81 & 4.75 & 4.70 & 4.54 & 4.69 & 4.50 & 4.68 & 4.44 \\
\hline Moisture & $\%$ & 10.67 & 11.69 & 10.44 & 11.31 & 11.53 & 12.27 & 11.28 & 11.94 & 11.68 & 12.23 & 11.42 & 11.52 \\
\hline Starch & $\%$ & 39.48 & 40.12 & 38.40 & 39.93 & 39.01 & 40.46 & 37.89 & 39.32 & 38.33 & 39.94 & 37.17 & 39.55 \\
\hline Sugars & $\%$ & 5.33 & 5.55 & 5.27 & 5.31 & 5.00 & 5.08 & 5.09 & 5.12 & 4.89 & 4.77 & 5.01 & 4.37 \\
\hline Non-starch polysaccharides & $\%$ & 16.42 & 16.13 & 16.66 & 16.08 & 19.54 & 19.06 & 19.48 & 19.24 & 21.16 & 21.03 & 21.06 & 21.20 \\
\hline $\begin{array}{l}\text { Digestible non-starch } \\
\text { polysaccharides }\end{array}$ & $\%$ & 9.08 & 8.80 & 9.10 & 8.70 & 10.30 & 9.92 & 10.29 & 9.92 & 11.51 & 11.17 & 11.32 & 11.05 \\
\hline $\begin{array}{c}\text { Net energy } \\
\text { Apparent ileal digestible amino } \\
\text { acids }\end{array}$ & Kcal & 2396 & 2396 & 2396 & 2396 & 2299 & 2299 & 2304 & 2302 & 2253 & 2255 & 2253 & 2253 \\
\hline Lys & $\%$ & 1.02 & 1.02 & 1.02 & 1.02 & 0.79 & 0.79 & 0.79 & 0.79 & 0.68 & 0.68 & 0.68 & 0.68 \\
\hline Met & $\%$ & 0.34 & 0.39 & 0.35 & 0.42 & 0.25 & 0.26 & 0.25 & 0.26 & 0.21 & 0.21 & 0.21 & 0.21 \\
\hline Met + Cys & $\%$ & 0.60 & 0.61 & 0.60 & 0.64 & 0.48 & 0.46 & 0.48 & 0.46 & 0.44 & 0.41 & 0.44 & 0.41 \\
\hline Thr & $\%$ & 0.66 & 0.66 & 0.66 & 0.66 & 0.51 & 0.51 & 0.52 & 0.52 & 0.44 & 0.44 & 0.45 & 0.44 \\
\hline Tryp & $\%$ & 0.19 & 0.19 & 0.19 & 0.19 & 0.15 & 0.15 & 0.15 & 0.15 & 0.14 & 0.13 & 0.14 & 0.13 \\
\hline Iso-Val & $\%$ & 0.61 & 0.53 & 0.61 & 0.53 & 0.50 & 0.41 & 0.50 & 0.42 & 0.47 & 0.38 & 0.47 & 0.38 \\
\hline Val & $\%$ & 0.70 & 0.64 & 0.70 & 0.64 & 0.59 & 0.50 & 0.59 & 0.50 & 0.56 & 0.47 & 0.57 & 0.47 \\
\hline Calcium & $\%$ & 0.70 & 0.70 & 0.70 & 0.70 & 0.65 & 0.65 & 0.62 & 0.62 & 0.62 & 0.61 & 0.62 & 0.61 \\
\hline Phosphorus total & $\%$ & 0.43 & 0.41 & 0.43 & 0.40 & 0.47 & 0.44 & 0.47 & 0.44 & 0.47 & 0.45 & 0.47 & 0.45 \\
\hline Potassium & $\%$ & 0.85 & 0.86 & 0.85 & 0.84 & 0.80 & 0.78 & 0.80 & 0.78 & 0.78 & 0.74 & 0.79 & 0.74 \\
\hline Sodium & $\%$ & 0.17 & 0.17 & 0.17 & 0.17 & 0.14 & 0.18 & 0.14 & 0.14 & 0.14 & 0.14 & 0.14 & 0.14 \\
\hline Digestible phosphorus & $\%$ & 0.27 & 0.28 & 0.27 & 0.27 & 0.27 & 0.27 & 0.27 & 0.27 & 0.25 & 0.26 & 0.26 & 0.25 \\
\hline Sulfur total & $\%$ & 0.27 & 0.28 & 0.27 & 0.28 & 0.24 & 0.23 & 0.23 & 0.23 & 0.22 & 0.21 & 0.22 & 0.21 \\
\hline
\end{tabular}


Table 2. Cont.

\begin{tabular}{|c|c|c|c|c|c|c|c|c|c|c|c|c|c|}
\hline \multirow[b]{2}{*}{ Composition } & \multirow[b]{2}{*}{ Unit } & \multicolumn{4}{|c|}{ Starter Diet } & \multicolumn{4}{|c|}{ Grower Diet } & \multicolumn{4}{|c|}{ Finisher Diet } \\
\hline & & $\mathrm{CON}$ & RCP & AD & CD & $\mathrm{CON}$ & RCP & AD & CD & $\mathrm{CON}$ & RCP & AD & CD \\
\hline Dietary electrolyte balance & meq & 215 & 220 & 215 & 220 & 198 & 200 & 199 & 201 & 193 & 195 & 194 & 195 \\
\hline Vit A -added & $\mathrm{IE} / \mathrm{kg}$ & 10,000 & 10,000 & 10,000 & 10,000 & 9719 & 9719 & 9719 & 9719 & 7758 & 7758 & 7758 & 7758 \\
\hline Vit $\mathrm{D}_{3}$-added & $\mathrm{IE} / \mathrm{kg}$ & 2000 & 2000 & 2000 & 2000 & 1996 & 1996 & 1996 & 1996 & 1842 & 1842 & 1842 & 1842 \\
\hline Vit E -added & $\mathrm{mg} / \mathrm{kg}$ & 120 & 120 & 120 & 120 & 101 & 101 & 101 & 101 & 99 & 99 & 99 & 99 \\
\hline Phytase-equivalent & $\mathrm{FU} / \mathrm{kg}$ & 1000 & 1000 & 1000 & 1000 & 758 & 758 & 758 & 758 & 657 & 657 & 657 & 657 \\
\hline \multicolumn{14}{|l|}{ Analyzed composition } \\
\hline Crude protein & $\%$ & 18.6 & 16.2 & 17.9 & 16.8 & 16.2 & 15.1 & 15.7 & 14.4 & 15.6 & 13.7 & 15.6 & 13.6 \\
\hline Crude fat & $\%$ & 5.0 & 4.9 & 5.3 & 5.4 & 4.4 & 4.3 & 4.4 & 4.7 & 4.1 & 4.1 & 4.4 & 4.4 \\
\hline Crude fiber & $\%$ & 4.2 & 4.2 & 4.3 & 3.9 & 5.5 & 5.2 & 5.2 & 5.7 & 5.7 & 5.7 & 5.8 & 6.2 \\
\hline Crude ash & $\%$ & 5.1 & 5.7 & 5.0 & 4.9 & 4.8 & 4.9 & 4.6 & 4.7 & 4.6 & 4.4 & 4.6 & 3.9 \\
\hline Sugar & $\%$ & 5.4 & 4.9 & 5.2 & 6.0 & 5.1 & 5.1 & 5.6 & 5.0 & 5.1 & 4.4 & 5.0 & 4.4 \\
\hline Starch & $\%$ & 35.7 & 36.8 & 35.9 & 36.2 & 36.8 & 38.7 & 38.2 & 36.4 & 37.5 & 40.0 & 37.2 & 37.5 \\
\hline Calcium & $\%$ & 0.84 & 1.17 & 0.76 & 0.77 & 0.74 & 0.72 & 0.70 & 0.79 & 0.68 & 0.64 & 0.68 & 0.76 \\
\hline Potassium & $\%$ & 0.81 & 0.83 & 0.84 & 0.84 & 0.79 & 0.75 & 0.76 & 0.76 & 0.76 & 0.72 & 0.78 & 0.81 \\
\hline Sodium & $\%$ & 0.15 & 0.15 & 0.17 & 0.17 & 0.14 & 0.15 & 0.13 & 0.13 & 0.13 & 0.13 & 0.14 & 0.13 \\
\hline Chlorine & $\%$ & 0.25 & 0.25 & 0.27 & 0.28 & 0.23 & 0.27 & 0.23 & 0.22 & 0.23 & 0.21 & 0.24 & 0.16 \\
\hline Sulfur total & $\%$ & 0.22 & 0.26 & 0.24 & 0.26 & 0.19 & 0.23 & 0.17 & 0.23 & 0.17 & 0.22 & 0.17 & 0.22 \\
\hline Benzoic & $\%$ & & & 0.87 & 0.65 & & & 0.70 & 0.88 & & & 0.83 & 0.94 \\
\hline Formic acid & $\%$ & & & 0.53 & 0.64 & & & 0.48 & 0.60 & & & 0.58 & 0.62 \\
\hline Dietary electrolyte balance & meq & 202 & 207 & 212 & 210 & 198 & 181 & 186 & 189 & 186 & 182 & 193 & 218 \\
\hline
\end{tabular}

$\mathrm{CON}=$ control diet, $\mathrm{RDP}=$ reduced crude protein diet, $\mathrm{AD}=$ acidifying diet, $\mathrm{CD}=$ combined diet $=$ reduced crude protein + acidifying diet, Dietary electrolyte balance was determined as $\mathrm{mEq}=\mathrm{Na}+\mathrm{K}-\mathrm{Cl}$.

Pigs were fed ad libitum until they reached $70 \mathrm{~kg}$ live weight, after which the amount of feed provided was adjusted, gradually increasing from 2.45 to $2.65 \mathrm{~kg}$ until the pigs reached the weight of $120 \mathrm{~kg}$. Feed was delivered once daily in a dry feeder at a single feeding place. Water was freely available via a drinking bowl. Feed and water intake were recorded every day. All pigs were weighed at the beginning and at the end of the experimental period, just before the morning feeding. In addition, at each feeding transition, five and nine weeks after the start of the experiment, pigs in four pens of each room were weighed. Average daily weight gain and feed efficiency were obtained from the feed intake and the increase in body weight (BW) during the experimental period. The daily water intake per pig per day during the 110-day experimental period was 5.11 per day. All pigs were slaughtered at the end of the experiment. Slaughtering BW, lean meat, muscle thickness and backfat thickness were measured according to Lambooij et al. [12].

Pigs were housed in 48 pens in four similar, mechanically ventilated and temperaturecontrolled rooms, at 12 pens per room. Rooms were fully separated from other rooms. All pigs in one room were fed the same starter, grower and finisher diet. Each pen had an equal number of male and female pigs. The size of the pens in rooms 9 (acidifying diet treatment) and 10 (reduced crude protein diet treatment) was $2.5 \times 5.0 \mathrm{~m}$, with a slatted floor at the rear $(2.5 \times 2.0 \mathrm{~m})$ and the front $(2.5 \times 1.15 \mathrm{~m})$ and a solid, convex floor in between. The size of the pens in rooms 11 (control diet treatment) and 12 (combined diet treatment) was $2.5 \times 4.85 \mathrm{~m}$, with a slatted floor at the rear $(2.5 \times 1.5 \mathrm{~m})$ and the front $(2.5 \times 0.55 \mathrm{~m})$ and a solid, convex floor in between.

Ventilation was achieved by central fans at the end of a ventilation channel. These fans sucked the air from outside into the rooms. Each room had two exhaust ducts with a measuring fan and a valve to control the amount of air that went through the ventilator. For each measuring fan, a calibration line was made on the spot with a measuring fan that was calibrated in a wind tunnel. The number of rotations of the measuring fan was counted, and the corresponding number of pulses was logged in the climate control system. Temperatures and humidities of the rooms were measured near the exhaust air ducts and were recorded every minute. The average temperatures and humidities of the rooms during the 110-day experimental period were $22.1{ }^{\circ} \mathrm{C}$ and $56.7 \% ; 23.6{ }^{\circ} \mathrm{C}$ and $67.0 \% ; 23.2{ }^{\circ} \mathrm{C}$ and $60.1 \% ; 23.0^{\circ} \mathrm{C}$ and $58.6 \%$ for the rooms with control, reduced $\mathrm{CP}$, manure acidifying and combined diets, respectively. 
Experimental diets were analyzed for dry matter, ash, crude protein, minerals, crude fiber, fat, starch, sugar, gross energy, some essential amino acids (AA), benzoic and formic acids. The AA (except Met, Cys and Trp) were assayed by ion-exchange column chromatography after hydrolysis for $23 \mathrm{~h}$ in $\mathrm{HCl}\left(6 \mathrm{~mol} \mathrm{~L}^{-1}\right)$. Cystine and Met were determined as cysteic acid and methionine sulfone after oxidation with performic acid before hydrolysis [13]. Tryptophane was determined according to Sato et al. [14]. Benzoic acid was analyzed with liquid chromatography with UV detection after aqueous extraction and purification of the samples. Regarding formic acid, after hydrolysis, an analysis of the extracts was performed using ion chromatography with conductivity detection. Benzoic acid and formic acid were analyzed at the lab of NutriControl, Veghel in the Netherlands.

Starch content was determined enzymatically according to the amyloglucosidase/hexokinase method (NEN 3574). Sugar was assayed according to the non-starch polysaccharides (NSP) procedure [15]. Crude fiber was determined gravimetrically after treatment with sulfuric acid and potassium hydroxide (ISO/DIS 6895). For total fat, samples were hydrolyzed with chloric acid, followed by extraction of fat with petroleum ether. The $\mathrm{Ca}, \mathrm{P}$, $\mathrm{Mg}, \mathrm{Na}, \mathrm{K}, \mathrm{Cu}$ and $\mathrm{Zn}$ contents were determined using inductively coupled plasma atomic emission spectrometry (ICP-AES). The $\mathrm{Cl}$ content was determined by the potentiometric titration of water-diluted solid samples with the chloride specific ion electrode (Jenway Chloride Meter, model PCLM3, Staffordshire, UK). For sulfate, samples were extracted with chloric acid. Sulfate was separated with ion chromatography using a water // sodium hydroxide gradient and an Ionpac AS 11 (Dionex, ThermoFisher Scientific, Waltham, MA, USA) as the column. Detection takes place by suppressed electric conductivity. Identification and quantification were achieved using an external standard solution. The DM was determined gravimetrically after $4 \mathrm{~h}$ at $103^{\circ} \mathrm{C}$ (ISO 6496). The content of ash was determined gravimetrically after ashing at $550{ }^{\circ} \mathrm{C}$ (ISO 5984). Nitrogen content was determined by the Kjeldahl method (ISO 5983). The analyzed dietary CP levels of the starter diets were $18.5 \%$ for $\mathrm{CON}$ and $\mathrm{AD}$ treatments and $16.5 \%$ for RDP and CD treatments. The analyzed dietary $\mathrm{CP}$ levels of the grower diets were $16.03 \%$ for $\mathrm{CON}$ and $\mathrm{AD}$ treatments and $14.02 \%$ for RDP and CD treatments. The analyzed dietary $\mathrm{CP}$ levels of the finisher diets were $15.52 \%$ for CON and $\mathrm{AD}$ treatments and $13.52 \%$ for RDP and CD treatments (Table 2).

\subsection{Sample Collection, Measurements and Calculations}

Measurements of ammonia emissions, fresh urine and feces, urine patches and manure characteristics were done every three weeks. In total, there were four rounds of measurements. In each round, the measurement lasted for four days. First, the ammonia emissions from each of the four pig rooms were continuously measured for one day. On the next day, fresh urine, feces, urine patches and manure samples from the manure pit were collected. On the third day, the manure pit was cleaned and filled with water up to $10 \mathrm{~cm}$ below the slatted floor for measuring ammonia emissions from the floor on the fourth day.

\subsubsection{Ammonia Emissions from the Animal House}

On the measurement days, as mentioned in paragraph 2.2, in each room, continuous measurements of ammonia concentration, ventilation flow, temperature and relative humidity were conducted. Ammonia concentrations were measured with a NOx (Model 200A Chemiluminescent NOx Analyzer, Teledyne API, San Diego, CA, USA) by sampling the inlet and outlet air inside the shafts of the fans and after ammonia had been converted to $\mathrm{NO}$ at $775{ }^{\circ} \mathrm{C}$, as described by Ogink et al. [16]. The analyzer was calibrated every three weeks. The ventilation rate was measured with a calibrated anemometer installed in the exhaust chimney in each room, as described by Mosquera et al. [17]. One anemometer was used in each room. Temperature and humidity of the outgoing air were measured just under the opening of the shaft by an Escort $\mathrm{T} / \mathrm{RH}$ sensor in combination with a logging system (ESCORT iLog Humidity Loggers, Aesch, Switzerland). Ammonia emissions from the different rooms were calculated from the difference in ammonia concentrations of the 
outgoing air and incoming air and from the ventilation rate. This included the ammonia emissions from the manure pit and the floor.

\subsubsection{Ammonia Emissions from Floor}

After the removal of manure from the manure pit, the manure pit was filled with water up to $10 \mathrm{~cm}$ below the slatted floor. This was done to make ammonia emissions from the manure pit equal to 0 . The ammonia concentration, temperature, humidity and ventilation rate were measured on the next day. Ammonia emissions from the floor were measured and calculated as they were with ammonia emissions from the animal house.

\subsubsection{Fresh Urine and Feces, Urine Patches and Manure Characteristics}

Fresh urine and fresh feces characteristics: Single urine and feces samples were taken from 12 pigs ( 6 male and 6 female, randomly chosen from 4 pens) per dietary treatment. The samples from each pig were kept separately in the first instance. Approximately $2 \mathrm{~mL}$ of urine from each urine sample was inserted with a pipette in a jar with $2 \mathrm{~mL}$ acid $\mathrm{HCl} 1 \mathrm{M}$ to stop urea conversion. Therefore, there were $2 \mathrm{~mL}$ of acid and $24 \mathrm{~mL}$ of urine in the jar. In the remaining urine, the $\mathrm{pH}$ was determined on the spot. In the lab, the fresh urine samples without acid were joined together on an equal mass basis and analyzed for $\mathrm{NH}_{4}-\mathrm{N}$, Total $\mathrm{N}$ and potassium. In these samples, the urine-urea before $\mathrm{NH}_{4}-\mathrm{N}$ analysis was first converted by the addition of urease. The fresh urine samples in acid were analyzed for $\mathrm{NH}_{4}-\mathrm{N}$.

The fresh feces samples were also joined together on an equal mass basis and analyzed for $\mathrm{NH}_{4}-\mathrm{N}$, N-total and potassium. Ammonium-N was determined spectrophotometrically according to NEN 6472 [18]. Manure $\mathrm{pH}$ was measured by a $\mathrm{pH}$ meter (Orion 520A) with an electrode (Orion 9104 SC). Potassium content was determined using an inductively coupled plasma atomic emission spectrometer (ICP-AES). Total nitrogen content was determined by the Kjeldahl method (ISO 5983).

Urine patch characteristics: The ammonium content and $\mathrm{pH}$ of urine were determined through the "filter method". For this purpose, 10 samples were taken at 10 representative locations in two pens of each room. Representative means of samples were taken from locations that were very soiled. Samples were taken by siphoning the urine through glass fiber filters, two of which were placed at each sample location. This included one filter in a jar with $10 \mathrm{~mL}$ acid $\mathrm{HCl} 1 \mathrm{M}$ and the other filter in a jar with $10 \mathrm{~mL}$ demineralized water.

Ten filters were combined into one composite sample in the jar with acid and one composite sample in the jar with water. After mixing, the $\mathrm{pH}$ was measured on the spot in the jar of filters in water. In the chemical laboratory, the jars with filters in water were analyzed for $\mathrm{NH}_{4}-\mathrm{N}$ and potassium content. It was ensured that all the urea was converted to ammonium (addition urease). Potassium was analyzed to determine how the $\mathrm{NH}_{4}-\mathrm{N} / \mathrm{K}$ ratio changed from fresh to urine patches. This provides an indication of the loss of $\mathrm{NH}_{4}-\mathrm{N}$ from the urine patch. The level of potassium in the urine puddles relative to the potassium content in the fresh urine gives an indication of the water evaporation. The jars with acid filters were analyzed for $\mathrm{NH}_{4}-\mathrm{N}$.

Upper layer manure characteristics: Single aggregate samples of the uppermost layer of manure in the manure pit were collected via the 'filter' method (absorption of samples of the uppermost layer of manure). We took 10 samples that were evenly distributed over the manure pit of two pens/room. At each sample site, two filters were taken. This included one filter in a jar with $10 \mathrm{~mL}$ acid $\mathrm{HCl} 1 \mathrm{M}$ and the other filter in a jar with $10 \mathrm{~mL}$ demineralized water. Samples of 10 locations were combined into one composite sample in the container with acid and one composite sample in the jar with water. After mixing, the $\mathrm{pH}$ was measured on the spot in the jars with water. In the chemical laboratory, in the jar with water, the ammonium and potassium contents were analyzed.

Manure characteristics: We took a one-liter sample of the manure from the manure pit during the discharge of the manure into the interim storage before it was pumped into an outside storage. During the discharge, a sample was taken at regular moments from the manure stream. The $\mathrm{pH}$ of the sample was measured directly in the manure bottle. At 
the lab, DM, ash, $\mathrm{NH}_{4}-\mathrm{N}$, total $\mathrm{N}$, potassium, sodium, chloride, phosphor, calcium and total volatile fatty acids concentrations were determined. In addition, from each bucket, two samples of $10 \mathrm{~g}$ were taken in fully airtight sealed jars of $60 \mathrm{~mL}$ with a rubber septum, which had been pre-weighed. The samples in airtight jars were used for determining the total inorganic carbonate (TIC) and alkalinity/acidity. All samples were stored at $-20{ }^{\circ} \mathrm{C}$ until the analyses. Volatile fatty acids in the manure were measured using a Packard 427 gas chromatograph, equipped with a flame ionization detector. TIC was measured by acidifying manure samples that had been stored in gas-tight bottles and measuring the volume of $\mathrm{CO}_{2}$ evolved [19]. The buffer capacity was determined by measuring the $\mathrm{pH}$ change in response to the addition of a small quantity of strong acid $(\mathrm{HCl})$ or strong base $(\mathrm{NaOH})$. Other manure characteristics were analyzed according to protocols, as mentioned in feed analyses.

\subsubsection{Ammonia Concentration at $1 \mathrm{~cm}$ and $10 \mathrm{~cm}$ above the Manure Pit}

The levels of ammonia concentration at $1 \mathrm{~cm}$ and $10 \mathrm{~cm}$ above the manure pit were measured once every three weeks. Each time the measurement lasted for about $30 \mathrm{~min}$. We measured it with a NOx monitor (Teledyne Model T200, San Diego, CA, USA), as described by Ogink et al. [16], every minute using a data logger system (Campbell Scientific, Inc, Logan, UT, USA). The final recorded ammonia concentration was the average of all oneminute recorded values.

\subsection{5. $\mathrm{pH}$ and Temperature Gradient in Manure}

The $\mathrm{pH}$ and temperature gradient in the manure of two pens/room were measured. The $\mathrm{pH}$ and temperature were measured at 0.50 and $5 \mathrm{~cm}$ from the surface of the manure.

\subsection{Statistical Analysis}

The effects of reduced crude protein or manure acidifying diets on animal performance (daily weight gain, feed intake, feed conversion ratio, slaughter data) were analyzed on pen level using ANOVA GenStat (Genstat Committee, 2014, VSN International Ltd, Hemel Hempstead, UK) with the following model.

$$
Y_{i j}=\mu+T_{i}+e_{i j}
$$

where: $\mathrm{Y}_{\mathrm{ij}}$ : dependent variables; $\mu$ : overall mean; $\mathrm{T}_{\mathrm{i}}=$ effects of $\operatorname{diet}(\mathrm{i}=1 \mathrm{CON} ; \mathrm{i}=2=\mathrm{RCP}$; $\mathrm{i}=3=\mathrm{AD} ; \mathrm{i}=4=\mathrm{CD}) ; \mathrm{e}_{\mathrm{ij}}=$ residual error.

The effects of reduced crude protein or manure acidifying diets on ammonia emission, urine, feces and manure characteristics were analyzed at room level using ANOVA GenStat (Genstat Committee, 2014, VSN International Ltd, Hemel Hempstead, UK) with the following model.

$$
\mathrm{Y}_{\mathrm{jklm}}=\mu+\mathrm{CP}_{\mathrm{i}}+\mathrm{AD}_{\mathrm{j}}+\mathrm{BR}_{\mathrm{K}}+\mathrm{BW}_{1}+\mathrm{e}_{\mathrm{ijklm}}
$$

where: $\mathrm{Y}_{\mathrm{ijklm}}$ : dependent variables, $\mu$ : overall mean; $\mathrm{CP}_{\mathrm{i}}=$ effects of protein $(\mathrm{i}=1=$ normal diet; $\mathrm{i}=2$ = reduced $\mathrm{CP}$ diet); $\mathrm{AD}_{\mathrm{j}}=$ effects of acidifying diet $(\mathrm{j}=1=$ normal diet; $\mathrm{j}=2$ = acidifying diet $) ; \mathrm{BR}_{\mathrm{k}}=$ effects of room block $(\mathrm{k}=1=\operatorname{room} 11$ and $12, \mathrm{k}=2=\operatorname{room} 9$ and 10); $\mathrm{BW}_{1}=$ Effect of sample collection day block $(1=4=$ day of sample collection, once every three weeks; four times); $\mathrm{e}_{\mathrm{ijklm}}$ : residual error.

The interaction effect between the reduced protein and acidifying diet treatments could not be included in the model, as it is intertwined with the effect of the room block. Research by Bakker et al. [20] has shown that the effects of feed measures aimed at reducing ammonia emissions by reducing the protein content and lowering the $\mathrm{pH}$ of urine and manure are additive and therefore do not interact with each other.

Data are presented as an arithmetic mean. A natural log transformation was applied to ammonia emissions since they were not normally distributed. 


\section{Results}

\subsection{Effects of Experimental Diets on Daily Gain, Daily Feed Intake and Feed Efficiency}

Effects of experimental diets on final body weight (BW), average daily feed intake (ADFI), average daily weight gain (ADG) and feed conversion ratio (FCR) are presented in Table 3. There were no significant differences in final BW among treatments. Average daily weight gain and ADFI were lowest in the CON treatment, followed by CD and AD treatments, and highest in the RCP treatment $(p<0.001)$. FCR did not show any significant difference among the treatments $(p>0.05)$.

Table 3. Effects of experimental diets on average daily feed intake, average daily weight gain and feed conversion ratio (mean \pm standard deviation, $n=12$ ).

\begin{tabular}{cccccc}
\hline Items & CON & RCP & AD & CD & $p$-Value \\
\hline Initial BW (kg) & $24.7 \pm 2.59$ & $25.2 \pm 3.80$ & $25.3 \pm 3.84$ & $24.7 \pm 2.58$ & 0.95 \\
Final BW (kg) & $123.8 \pm 2.88$ & $125.3 \pm 3.67$ & $123.0 \pm 4.17$ & $124.9 \pm 2.78$ & 0.33 \\
$\begin{array}{c}\text { Average daily } \\
\text { weight gain (g/day) } \\
\text { Feed intake } \\
\begin{array}{c}\text { (kg/day) } \\
\text { Feed conversion } \\
\text { ratio }\end{array}\end{array}$ & $2.16^{\mathrm{a}} \pm 0.04$ & $2.30^{\mathrm{b}} \pm 0.05$ & $2.25^{\mathrm{c}} \pm 0.08$ & $2.24^{\mathrm{c}} \pm 0.03$ & $<0.001$ \\
$\begin{array}{c}\text { (kg feed/kg weight } \\
\text { gain) }\end{array}$ & $2.47 \pm 0.03$ & $2.50 \pm 0.06$ & $2.50 \pm 0.10$ & $2.50 \pm 0.05$ & 0.46 \\
\hline
\end{tabular}

$\mathrm{CON}=$ control diet, $\mathrm{RCP}=$ reduced crude protein diet, $\mathrm{AD}=$ acidifying diet, $\mathrm{CD}=$ combined diet. $^{\mathrm{a}, \mathrm{b}, \mathrm{c}}$ Means within rows missing a common superscript letter are different at $p<0.05$.

\subsection{Effects of Experimental Diets on Slaughter Quality}

Effects of experimental diets on meat performance are presented in Table 4. Results show that experimental diets did not affect slaughtering BW, lean meat percentage or backfat thickness $(p>0.05)$. However, muscle thickness was highest in CD and lowest in RCP diets $(p=0.001)$.

Table 4. Effects experimental diets on meat performance (mean \pm standard deviation, $n=12$ ).

\begin{tabular}{cccccc}
\hline Items & CON & RCP & AD & CD & $p$-Value \\
\hline $\begin{array}{c}\text { Slaughtering BW } \\
(\mathrm{kg})\end{array}$ & $93.6 \pm 1.8$ & $96.1 \pm 3.0$ & $95.1 \pm 3.1$ & $96.0 \pm 2.5$ & 0.10 \\
$\begin{array}{c}\text { Lean meat (\%) } \\
\text { Muscle thickness } \\
(\mathrm{mm})\end{array}$ & $59.3 \pm 0.5$ & $58.9 \pm 0.5$ & $59.1 \pm 0.6$ & $59.0 \pm 0.4$ & 0.34 \\
$\begin{array}{c}\text { Back fat } \\
\text { ab } \pm 2.0\end{array}$ & $63.2^{\mathrm{c}} \pm 1.6$ & $63.5^{\mathrm{ac}} \pm 2.6$ & $66.5^{\mathrm{b}} \pm 1.8$ & 0.001 \\
thickness (mm) & $13.7 \pm 0.72$ & $14.2 \pm 0.8$ & $14.0 \pm 0.9$ & $14.1 \pm 0.6$ & 0.34
\end{tabular}

$\mathrm{CON}=$ control diet, $\mathrm{RCP}=$ reduced crude protein diet, $\mathrm{AD}=$ acidifying diet, $\mathrm{CD}=$ combined diet. ${ }^{\mathrm{a}, \mathrm{b}, \mathrm{c}}$ Means within rows missing a common superscript letter are different at $p<0.05$.

\subsection{Effects of Experimental Diets on Urine and Feces Characteristics}

Characteristics of urine and feces among the experimental pigs are presented in Table 5. The total $\mathrm{N}$ in feces was reduced when pigs were fed reduced crude protein diets $(p=0.01)$. Acidifying diets reduced $\mathrm{pH}$ fresh urine at the spot measured directly inside the pig house $(p<0.001)$ and $\mathrm{pH}$ urine soiled $(p=0.07)$ and $\mathrm{NH}_{4}-\mathrm{N}$ of upper manure in the jar with water $(p=0.06)$. Other items did not show significant differences $(p>0.05)$. 
Table 5. Effects of experimental diets on urine and feces characteristics (mean \pm standard deviation, $n=4)$.

\begin{tabular}{|c|c|c|c|c|c|c|}
\hline \multirow{2}{*}{ Items } & \multirow{2}{*}{ CON } & \multirow{2}{*}{ RCP } & \multirow{2}{*}{ AD } & \multirow{2}{*}{ CD } & \multicolumn{2}{|c|}{$p$-Value } \\
\hline & & & & & Protein & Acidifying \\
\hline Total $\mathrm{N}$ in feces $(\mathrm{g} / \mathrm{kg})$ & $9.23 \pm 1.10$ & $8.84 \pm 0.98$ & $9.55 \pm 0.77$ & $8.21 \pm 1.06$ & 0.01 & 0.61 \\
\hline $\mathrm{NH}_{4}-\mathrm{N}$ in feces $(\mathrm{g} / \mathrm{kg})$ & $1.02 \pm 0.18$ & $0.95 \pm 0.19$ & $0.96 \pm 0.05$ & $0.99 \pm 0.09$ & 0.79 & 0.90 \\
\hline $\mathrm{K}$ in feces $(\mathrm{g} / \mathrm{kg})$ & $3.34 \pm 0.28$ & $3.10 \pm 0.18$ & $3.12 \pm 0.29$ & $2.98 \pm 0.09$ & 0.11 & 0.15 \\
\hline $\mathrm{pH}$ fresh urine at the spot & $7.08 \pm 0.18$ & $7.38 \pm 0.43$ & $6.26 \pm 0.68$ & $6.37 \pm 0.76$ & 0.28 & 0.001 \\
\hline $\begin{array}{l}\text { Urinary } \mathrm{NH}_{4}-\mathrm{N} \text { in jar without } \\
\text { acid }(\mathrm{g} / \mathrm{kg})\end{array}$ & $7.89 \pm 2.30$ & $5.82 \pm 4.83$ & $6.60 \pm 1.99$ & $6.39 \pm 2.37$ & 0.38 & 0.77 \\
\hline $\begin{array}{l}\text { Urinary total } \mathrm{N} \text { in jar without } \\
\text { acid }(\mathrm{g} / \mathrm{kg})\end{array}$ & $8.86 \pm 2.59$ & $6.92 \pm 5.80$ & $8.17 \pm 1.94$ & $8.14 \pm 2.52$ & 0.48 & 0.85 \\
\hline $\begin{array}{c}\text { Urinary } \mathrm{K} \text { in jar without acid } \\
\qquad(\mathrm{g} / \mathrm{kg})\end{array}$ & $5.29 \pm 2.07$ & $5.24 \pm 2.48$ & $5.21 \pm 0.47$ & $5.87 \pm 1.66$ & 0.66 & 0.68 \\
\hline $\begin{array}{l}\text { Urinary } \mathrm{NH}_{4}-\mathrm{N} \text { in jar with acid } \\
(\mathrm{mg} / \mathrm{kg})\end{array}$ & $849 \pm 574$ & $519 \pm 320.68$ & $648 \pm 164$ & $977 \pm 364$ & 0.09 & 0.63 \\
\hline $\begin{array}{l}\mathrm{pH} \text { of urine patches in jar with } \\
\text { water at the spot }\end{array}$ & $8.59 \pm 0.50$ & $8.25 \pm 0.50$ & $8.01 \pm 0.01$ & $8.14 \pm 0.28$ & 0.59 & 0.10 \\
\hline $\mathrm{pH}$ of urine soiled & $8.46 \pm 0.13$ & $7.89 \pm 0.22$ & $7.83 \pm 0.44$ & $7.76 \pm 0.55$ & 0.12 & 0.07 \\
\hline $\begin{array}{l}\mathrm{NH}_{4}-\mathrm{N} \text { of urine patches in jar } \\
\text { with water }(\mathrm{mg} / \mathrm{kg})\end{array}$ & $3483 \pm 3447$ & $7338 \pm 1121$ & $3451 \pm 1753$ & $2879 \pm 1964$ & 0.51 & 0.40 \\
\hline $\begin{array}{l}\text { K of urine patches in jar with } \\
\text { water }(\mathrm{mg} / \mathrm{kg})\end{array}$ & $1152 \pm 526$ & $672 \pm 347$ & $697 \pm 480$ & $1209 \pm 705$ & 0.94 & 0.85 \\
\hline $\begin{array}{c}\mathrm{NH}_{4}-\mathrm{N} \text { of urine patches in jar } \\
\text { with acid }(\mathrm{mg} / \mathrm{kg})\end{array}$ & $2737 \pm 1538$ & $1391 \pm 1677$ & $1940 \pm 1182$ & $1800 \pm 1215$ & 0.09 & 0.63 \\
\hline $\begin{array}{l}\mathrm{pH} \text { of upper manure in jar with } \\
\text { water at the spot }\end{array}$ & $7.90 \pm 0.21$ & $7.90 \pm 0.20$ & $8.00 \pm 0.01$ & $8.03 \pm 0.05$ & 0.12 & 0.77 \\
\hline $\begin{array}{l}\mathrm{NH}_{4}-\mathrm{N} \text { of upper manure in jar } \\
\text { with water }(\mathrm{mg} / \mathrm{kg})\end{array}$ & $4151 \pm 1235$ & $2891 \pm 1135$ & $2548 \pm 1328$ & $3562 \pm 1096$ & 0.58 & 0.06 \\
\hline
\end{tabular}

$\mathrm{CON}=$ control diet, $\mathrm{RCP}=$ reduced crude protein diet, $\mathrm{AD}=$ acidifying diet, $\mathrm{CD}=$ combined diet.

\subsection{Effects of Experimental Diets on Manure Characteristics}

Manure characteristics among the experimental pigs are presented in Table 6. Reducing dietary crude protein level or acidifying diets did not affect manure DM, concentrations of total ash, $\mathrm{K}, \mathrm{Na}, \mathrm{P}, \mathrm{Cl}, \mathrm{Ca}$, total volatile fatty acid (VFA) and acetic, propionic, iso-butyric, iso-pentanoic, pentanoic acids $(p>0.05)$. Manure $\mathrm{pH}$ measured at the spot was lower with reduced $\mathrm{CP}$ diets $(p=0.06)$, while acidifying diets did not affect manure $\mathrm{pH}$ measured on the spot $(p>0.05)$. Total $\mathrm{N}$ was reduced when pigs were fed reduced CP diets $(p=0.04)$ or acidifying diets $(p=0.07)$. Reducing dietary $\mathrm{CP}$ levels or acidifying diets reduced $\mathrm{NH}_{4}-\mathrm{N}$ in the manure $(p<0.05)$. The buffer capacity was significantly increased when $\mathrm{CP}$ was reduced $(p<0.001)$. Manure TIC was lower when pigs were fed reduced CP or acidifying diets $(p<0.001)$.

\subsection{Effects of Experimental Diets on Ammonia Emission}

Table 7 shows the effects of experimental diets on $\mathrm{pH}$ in manure at depths of $0.5 \mathrm{~cm}$ and $5 \mathrm{~cm}$ from the manure surface, ammonia concentration at $1 \mathrm{~cm}$ and $10 \mathrm{~cm}$ above the manure surface and ammonia emissions from the floor and the animal house. Reducing dietary $\mathrm{CP}$ level reduced the manure $\mathrm{pH}$ measured to a depth of $0.5 \mathrm{~cm}(p=0.07)$ and $5 \mathrm{~cm}$ $(p=0.003)$ from the manure surface; ammonia concentration at $1 \mathrm{~cm}(p=0.02)$ and at $10 \mathrm{~cm}$ $(p=0.02)$ above the manure surface; and ammonia emission from the floor $(p=0.06)$ and from the animal house $(p=0.08)$. However, acidifying diets did not affect those parameters $(p>0.05)$. 
Table 6. Effects of experimental diets on manure characteristics (mean \pm standard deviation, $n=4$ ).

\begin{tabular}{|c|c|c|c|c|c|c|}
\hline \multirow{2}{*}{ Items } & \multirow{2}{*}{$\mathrm{CON}$} & \multirow{2}{*}{$\mathbf{R C P}$} & \multirow{2}{*}{ AD } & \multirow{2}{*}{ CD } & \multicolumn{2}{|c|}{$p$-Value } \\
\hline & & & & & Protein & Acidifying \\
\hline $\mathrm{pH}$ at the spot & $7.39 \pm 0.46$ & $6.94 \pm 0.08$ & $7.03 \pm 0.12$ & $6.99 \pm 0.04$ & 0.06 & 0.20 \\
\hline Dry matter (g/kg) & $97.7 \pm 9.2$ & $93.2 \pm 8.9$ & $86.4 \pm 15.9$ & $104.5 \pm 10.4$ & 0.15 & 0.99 \\
\hline Ash $(\mathrm{g} / \mathrm{kg})$ & $18.90 \pm 1.56$ & $19.27 \pm 1.62$ & $18.77 \pm 2.40$ & $19.65 \pm 1.38$ & 0.30 & 0.83 \\
\hline $\mathrm{NH}_{4}-\mathrm{N}(\mathrm{g} / \mathrm{kg})$ & $4.03 \pm 0.51$ & $3.23 \pm 0.52$ & $4.62 \pm 0.73$ & $3.90 \pm 0.47$ & 0.02 & 0.04 \\
\hline Total-N (g/kg) & $6.88 \pm 0.53$ & $5.93 \pm 0.58$ & $7.28 \pm 0.59$ & $6.75 \pm 0.42$ & 0.04 & 0.07 \\
\hline $\mathrm{K}(\mathrm{g} / \mathrm{kg})$ & $3.98 \pm 0.39$ & $3.70 \pm 0.10$ & $4.19 \pm 0.18$ & $4.08 \pm 0.45$ & 0.20 & 0.07 \\
\hline $\mathrm{Na}(\mathrm{g} / \mathrm{kg})$ & $0.65 \pm 0.09$ & $0.64 \pm 0.09$ & $0.69 \pm 0.02$ & $0.68 \pm 0.10$ & 0.82 & 0.43 \\
\hline $\mathrm{P}(\mathrm{g} / \mathrm{kg})$ & $1.32 \pm 0.12$ & $1.24 \pm 0.09$ & $1.18 \pm 0.15$ & $1.36 \pm 0.17$ & 0.44 & 0.87 \\
\hline $\mathrm{Cl}(\mathrm{g} / \mathrm{kg})$ & $0.64 \pm 0.07$ & $0.69 \pm 0.06$ & $0.74 \pm 0.08$ & $0.67 \pm 0.17$ & 0.91 & 0.51 \\
\hline $\mathrm{Ca}(\mathrm{g} / \mathrm{kg})$ & $1.89 \pm 0.14$ & $2.25 \pm 0.52$ & $1.85 \pm 0.65$ & $2.25 \pm 0.38$ & 0.06 & 0.90 \\
\hline Acetic acid (g/kg) & $6.56 \pm 1.86$ & $6.79 \pm 1.91$ & $7.18 \pm 2.05$ & $9.35 \pm 0.90$ & 0.19 & 0.09 \\
\hline Propionic acid (g/kg) & $2.44 \pm 0.37$ & $2.97 \pm 0.62$ & $2.56 \pm 0.61$ & $2.62 \pm 0.46$ & 0.26 & 0.64 \\
\hline Iso-Butyric acid $(\mathrm{g} / \mathrm{kg})$ & $0.72 \pm 0.08$ & $0.70 \pm 0.10$ & $0.72 \pm 0.17$ & $0.63 \pm 0.08$ & 0.28 & 0.46 \\
\hline Butyric acid $(\mathrm{g} / \mathrm{kg})$ & $3.04 \pm 0.67$ & $2.65 \pm 0.40$ & $2.36 \pm 0.89$ & $3.24 \pm 0.74$ & 0.31 & 0.85 \\
\hline Iso-Pentanoic $(\mathrm{g} / \mathrm{kg})$ & $1.00 \pm 0.09$ & $0.97 \pm 0.11$ & $1.00 \pm 0.18$ & $0.96 \pm 0.10$ & 0.41 & 0.82 \\
\hline Pentanoic acid (g/kg) & $0.38 \pm 0.07$ & $0.49 \pm 0.09$ & $0.35 \pm 0.12$ & $0.41 \pm 0.08$ & 0.08 & 0.25 \\
\hline Total VFA $(\mathrm{g} / \mathrm{kg})$ & $14.14 \pm 2.76$ & $14.57 \pm 2.52$ & $14.17 \pm 3.70$ & $17.20 \pm 2.27$ & 0.19 & 0.31 \\
\hline Buffer capacity & $0.026 \pm 0.003$ & $0.040 \pm 0.005$ & $0.036 \pm 0.004$ & $0.034 \pm 0.004$ & 0.001 & 0.10 \\
\hline Manure TIC $(\mathrm{mol} / \mathrm{kg})$ & $0.184 \pm 0.034$ & $0.114 \pm 0.016$ & $0.105 \pm 0.008$ & $0.112 \pm 0.017$ & 0.009 & 0.002 \\
\hline
\end{tabular}

$\mathrm{CON}=$ control diet, $\mathrm{RCP}=$ reduced crude protein diet, $\mathrm{AD}=$ acidifying diet, $\mathrm{CD}=$ combined diet, $\mathrm{VFA}$ : volatile fatty acids, TIC: total inorganic carbon.

Table 7. $\mathrm{pH}$ and ammonia emissions from growing-finishing pig house as affected by experimental diets (mean \pm standard deviation, $n=4$ ).

\begin{tabular}{|c|c|c|c|c|c|c|}
\hline \multirow{2}{*}{ Items } & \multirow{2}{*}{ CON } & \multirow{2}{*}{$\mathrm{RCP}$} & \multirow{2}{*}{ AD } & \multirow{2}{*}{ CD } & \multicolumn{2}{|c|}{$p$-Value } \\
\hline & & & & & Protein & Acidifying \\
\hline $\mathrm{pH}$ at $0.5 \mathrm{~cm}$ depth from the manure surface & $8.48 \pm 0.41$ & $7.56 \pm 0.13$ & $7.79 \pm 0.13$ & $8.01 \pm 0.52$ & 0.07 & 0.49 \\
\hline $\mathrm{pH}$ at $5 \mathrm{~cm}$ depth from the manure surface & $7.79 \pm 0.31$ & $6.94 \pm 0.23$ & $7.19 \pm 0.08$ & $7.11 \pm 0.23$ & 0.003 & 0.09 \\
\hline $\begin{array}{l}\text { Ammonia concentration at } 1 \mathrm{~cm} \text { above } \\
\left(\text { the manure surface }\left(\mathrm{mg} / \mathrm{m}^{3}\right)\right.\end{array}$ & $15.66 \pm 6.12$ & $8.02 \pm 2.19$ & $9.89 \pm 1.82$ & $6.50 \pm 1.43$ & 0.02 & 0.09 \\
\hline $\begin{array}{l}\text { Ammonia concentration at } 10 \mathrm{~cm} \text { above } \\
\text { (the manure surface }\left(\mathrm{mg} / \mathrm{m}^{3}\right)\end{array}$ & $9.55 \pm 3.31$ & $7.23 \pm 2.53$ & $8.96 \pm 3.43$ & $5.79 \pm 1.83$ & 0.02 & 0.42 \\
\hline $\mathrm{NH}_{3}$ emission from the floor (g/day) & $1.91 \pm 1.18$ & $1.03 \pm 0.67$ & $1.34 \pm 1.19$ & $1.35 \pm 0.90$ & 0.06 & 0.41 \\
\hline $\mathrm{NH}_{3}$ emission from animal house (g/day) & $3.90 \pm 1.38$ & $2.68 \pm 1.01$ & $3.03 \pm 1.57$ & $3.03 \pm 0.74$ & 0.08 & 0.42 \\
\hline
\end{tabular}

$\mathrm{CON}=$ control diet, $\mathrm{RCP}=$ reduced crude protein diet, $\mathrm{AD}=$ acidifying diet, $\mathrm{CD}=$ combined diet.

\section{Discussion}

Dietary nitrogen is the main cause of high levels of ammonia production on pig farms. According to Aarnink [21], 30\% of the nitrogen in the diet is deposited in the body of growing-finishing pigs and $70 \%$ is excreted via urine and feces. Almost half of the excreted nitrogen is emitted during the storage of the manure inside the pig house and during the surface application of the manure. Changing the pig feed and the feeding strategy has been shown to be effective strategies to reduce ammonia emissions in the pig production facilities [10]. Two main feed and feeding strategies to reduce emissions are: (i) reducing nitrogen excretion by lowering the protein level in the diet and (ii) lowering the $\mathrm{pH}$ of the manure (by lowering the $\mathrm{pH}$ of feces and/or lowering the $\mathrm{pH}$ of urine). The latter can be achieved by changing the electrolyte balance of the diet. However, these two strategies were mainly tested in vitro or in controlled conditions such as restricted water intake [22-26] or measured above the manure pits $[27,28]$. In our current study, we applied CP levels (from $18.5 \%$ to $16.5 \%$; $16.5 \%$ to $14.5 \%$; and $15.5 \%$ to $13.5 \%$ for starter, grower and finisher diets, respectively) close to the target levels for the $\mathrm{CP}$ content in commercial diets described in the Framework code as good agricultural practice for reducing ammonia emissions (as 
published by the UN economic commission in Europe) [29]. Furthermore, the fact that we measured ammonia emissions from the floor and the pig house gave the results of our studies realistic meaning and produced ramifications that can be applied directly in commercial pig farms.

In our study, reduced CP diets decreased total $\mathrm{N}$ in feces $(p=0.01)$ and in manure $(p=0.04)$, urinary $\mathrm{NH}_{4}-\mathrm{N}$ in jar with acid $(p=0.09), \mathrm{NH}_{4}-\mathrm{N}$ of urine patches in jar with acid $(p=0.09)$, manure $\mathrm{NH}_{4}-\mathrm{N}(p=0.02)$, manure TIC $(p=0.009)$ and increased manure buffer capacity $(p=0.001)$. Reduced CP diets have been shown in the literature to decrease $\mathrm{N}$ excretion in feces, urine and manure (urine + feces). The urinary nitrogen of finishing pigs decreased linearly by lowering dietary CP levels from 16.8 to $15.9 ; 14.8$ and $13.6 \%$ [30]. According to $\mathrm{O}^{\prime}$ Connell et al. [31], finishing pigs that were offered diets containing 14\% $\mathrm{CP}$ excreted less nitrogen, urinary nitrogen and fecal nitrogen than those offered diets containing 16\% CP. Reduced CP diets supplemented with crystalline amino acids (AA) have been shown to reduce fecal nitrogen excretions by $25-30 \%$ [32,33]. According to Portejoie et al. [34], lowering dietary CP from $20 \%$ to $16 \%$ and $12 \%$, while maintaining similar levels of essential AAs, reduced total $\mathrm{N}$ content in manure from 5.48 to 4.30 and $3.05 \mathrm{~g} \mathrm{~N} \mathrm{~kg}^{-1}$, respectively.

The $\mathrm{pH}$ has a direct effect on ammonia emissions, since both urinary nitrogen and fecal nitrogen are further converted to ammonium $\left(\mathrm{NH}_{4}{ }^{+}\right)$at a low $\mathrm{pH}$ and to ammonia $\left(\mathrm{NH}_{3}\right)$ at a high $\mathrm{pH}$ [35]. In our study, reduced CP diets reduced the $\mathrm{pH}$ at depths of both $0.5 \mathrm{~cm}(p=0.07)$ and $5 \mathrm{~cm}(p=0.003)$ from the manure surface and decreased manure $\mathrm{pH}$ on the spot $(p=0.06)$ and $\mathrm{pH}$ of urine soiled on the floor $(p=0.07)$; this confirms previous findings. According to Portejoie et al. [34], the $\mathrm{pH}$ of the manure decreased by 1.3 units when dietary CP decreased from $20 \%$ to $12 \%$. According to Shriver et al. [36] and Aarnink and Verstegen [35], reduced CP diets supplemented with AA decrease not only nitrogen excretion but also manure $\mathrm{pH}$, which inhibits the conversion of ammonium $\left(\mathrm{NH}_{4}^{+}\right)$to ammonia, thus reducing ammonia emissions.

Ammonia emissions depend on urine, feces and manure characteristics, such as total $\mathrm{N}, \mathrm{NH}_{4}-\mathrm{N}$ and $\mathrm{pH}$. Reduced $\mathrm{CP}$ diets decreased manure $\mathrm{pH}$ and $\mathrm{N}$ excretions in feces and manure, and thus, the ammonia concentrations and emissions. In our study, a $2 \%$ unit reduction in dietary $\mathrm{CP}$ reduced ammonia concentrations at $1 \mathrm{~cm}$ and $10 \mathrm{~cm}$ above the manure surface by $49 \%$ and $24 \%$, respectively; ammonia emission from the floor and from the animal house were reduced by $46 \%$ and $31 \%$, respectively. Madrid et al. [37] found that a reduction in dietary $\mathrm{CP}$ of $1 \%$ and $2 \%$ of growing and finishing pigs, accompanied by supplementation with crystalline amino acid, reduced ammonia emissions from the chambers (pigs were kept in chambers) by $19.9 \%$ and $27.3 \%$, respectively. According to Hansen et al. [38], ammonia emissions from pig houses were reduced by $23 \%$ when finishing pigs were fed a low-protein, compared to a standard protein, diet containing 136 or $159 \mathrm{~g}$ crude protein $/ \mathrm{kg}$ diet, respectively (2.3\% unit reduction). It is well documented in the literature that for each $1 \%$ unit reduction in dietary $\mathrm{CP}$, when combined with AA supplementation, the estimated ammonia emissions (measured via in vitro studies or measured directly above the manure pit) are reduced by $10 \%[24,39,40]$. The total reduction of ammonia emissions from the animal houses, by lowering dietary CP levels in the current study and others, was higher than that from in vitro studies or from the manure pit, which is in line with our study finding a stronger effect of $\mathrm{CP}$ reduction on floor emissions compared to the animal house emissions.

Acidifying diets to lower the urine and manure $\mathrm{pH}$ is one of the feed strategies to reduce ammonia emissions. In our study, acidifying diets by adding benzoic acid $(10 \mathrm{~g} / \mathrm{kg})$ combined with replacing a portion of the $\mathrm{CaCO}_{3}$ by about $10 \mathrm{~g} \mathrm{Ca-formate} / \mathrm{kg}$ diet (on Ca-equivalent basis) reduced the $\mathrm{pH}$ of fresh urine on the spot $(p<0.01)$ and the $\mathrm{pH}$ of soiled urine $(p=0.07)$, but did not affect the manure $\mathrm{pH}$ measured on the spot, nor the $\mathrm{pH}$ at depths of $0.5 \mathrm{~cm}$ and $5 \mathrm{~cm}$ from the manure surface $(p>0.05)$. According to Bühler et al. [41], the addition of benzoic acid (1\%) to the diet of pigs from $26 \mathrm{~kg}$ to $100 \mathrm{~kg}$ reduced urinary $\mathrm{pH}$ by about one $\mathrm{pH}$-unit. Kluge et al. [42] reported that the relationship between benzoic 
acid intake and the urinary $\mathrm{pH}$ response was linear. Marie-Line Daumer et al. [43] declared that nitrogen excretion and the urine and manure $\mathrm{pH}$ of growing pigs were decreased when $1 \%$ benzoic acid was added to the diet. Some kinds of acid salts have been added to diets to reduce ammonia emissions based on the principle of reducing the $\mathrm{pH}$. According to Kim et al. [44], urine $\mathrm{pH}$ was reduced when replacing di-calcium-phosphate $\left(\mathrm{CaHPO}_{4}\right)$ and calcium carbonate $\left(\mathrm{CaCO}_{3}\right)$ with phosphoric acid $\left(\mathrm{H}_{3} \mathrm{PO}_{4}\right)$ and calcium sulfate $\left(\mathrm{CaSO}_{4}\right)$. Canh et al. [23] reported that replacing calcium carbonate with calcium sulfate, calcium chloride $\left(\mathrm{CaCl}_{2}\right)$ or calcium benzoate $\left(\mathrm{Ca}\left(\mathrm{C}_{7} \mathrm{H}_{5} \mathrm{O}_{2}\right)_{2}\right)$ significantly lowered the $\mathrm{pH}$ of urine and manure.

Acidifying diets did not reduce manure $\mathrm{pH}$ or ammonia concentrations above the manure surface, and thus, ammonia emissions from the pig house $(p>0.05)$. While supplementing with acid salts and/or organic acids has been well proven in in vitro studies $[23,43,44]$ to reduce urinary and manure $\mathrm{pH}$, and thus ammonia emissions, it was not confirmed in our in vivo studies. This is in opposition to the findings of Hansen et al. [45], where adding 3\% of benzoic acid to the diet of finishing pigs reduced ammonia emissions from the chamber by $57 \%$. Supplementing diets with a mixture of acid salt $(70 \%$ benzoic acid, $16.5 \%$ calcium salts, $6.5 \%$ formic acid and $7.0 \%$ propionic acid) comprising $1 \%$ and $2 \%$ of the feed, respectively, for starter and growing-finishing pigs reduced ammonia emission from the pig houses by $40 \%$ [46]. Probably, different amounts of acid salts and organic acids used in the various studies accounted for inconsistent results in terms of ammonia emission reduction from the pig house. In addition, in our study, manure has a high buffer capacity, and that might also be the reason that the effect of the acidifying diet was rather low. The buffer capacity of the protein treatment was the highest. This could point to an interaction between the protein and acidification treatment in the CD treatment. In this study, reduced protein and acidifying diet treatments could not be tested, as they were intertwined with the effect of room block. If an interaction effect of both treatments occurred, the single effect of acidification could be underestimated.

Reducing CP levels can decrease ammonia emissions from the animal house. Therefore, this dietary measure can be applied in growing and finishing pig production to reduce ammonia emissions. One of the important concerns of the producers is whether animal performance will be reduced when reducing CP levels are applied to reduce ammonia emissions. The current study found that reducing CP increased ADG $(p<0.05)$. This was the result of increasing the daily feed intake $(p<0.05)$. The feed conversion ratio was not affected by reduced CP diets $(p>0.05)$. Reduced CP diets did not affect meat performance (slaughtering body weight, lean meat, backfat thickness), except that the muscle thickness was reduced when lowering CP and acidifying diets. These results are in line with previous findings. Madrid et al. [37] found that a $2 \%$ reduction in the dietary CP of growing and finishing pigs supplemented with crystalline amino acid had no detrimental effects on growth performance, but did reduce muscle depth at the time of slaughter. Similarly, a $2.3 \%$ reduction of dietary CP for finishing pigs (from $15.9 \%$ to $13.6 \%$ ) while simultaneously supplementing the indispensable amino acids did not impair growth, feed utilization, nor meat percentage [38]. Nørgaard et al. [30] indicated that the CP could be decreased to $136 \mathrm{~g} / \mathrm{kg}$ as-fed for growing pigs in the weight range of 50-100 kg with no negative impact on growth performance and carcass traits. Le et al. [28] and Le et al. [27] found similar ADGs of pigs fed diets with CP levels of $12 \%, 15 \%$ and $18 \%$ supplemented with essential amino acids. Oldenburg and Heinrichs [47] found no negative effects on the performance and leanness of pigs between 50 and $110 \mathrm{~kg}$ when CP levels in diets were reduced from $17 \%$ to $13.5 \%$. According to Lopez et al. [48] and Hahn et al. [49], pigs fed reduced-CP diets (a reduction of 3.5 to $4 \%$ ) supplemented with AA had similar carcass characteristics to pigs fed diets with a normal CP.

\section{Conclusions}

This study demonstrated that decreasing the dietary crude protein level by $2 \%$ units reduced ammonia emission from the floor and from the pig house by $46 \%$ and $31 \%$, 
respectively. Reduced $\mathrm{CP}$ diets decreased the total $\mathrm{N}$ in feces and in manure, manure $\mathrm{NH}_{4}-\mathrm{N}(p<0.05), \mathrm{pH}$ at depths of $0.5 \mathrm{~cm}(p=0.07)$ and at $5 \mathrm{~cm}(p=0.003)$ from the manure surface, manure $\mathrm{pH}$ at the spot $(p=0.06)$ and $\mathrm{pH}$ of urine soiled on the floor $(p=0.07)$. Acidifying diets (by adding $10 \mathrm{~g}$ benzoic acid $/ \mathrm{kg}$ diet as well as replacing a portion of the $\mathrm{CaCO}_{3}$ by about $10 \mathrm{~g}$ Ca-formate $/ \mathrm{kg}$ diet) did not significantly reduce ammonia emissions from the floor and the pig house, manure $\mathrm{pH}$ measured at the spot, nor $\mathrm{pH}$ at the depths of $0.5 \mathrm{~cm}$ and $5 \mathrm{~cm}$ from the manure surface $(p>0.05)$, although the $\mathrm{pH}$ of fresh urine at the spot $(p<0.01)$ and the $\mathrm{pH}$ of soiled urine $(p=0.07)$ was reduced. The decreased crude protein diet gave a higher growth rate in growing-finishing pigs when compared with the control diet; the growth rate of the acidifying diet was in between. Reducing dietary crude protein is a solution to reducing ammonia emissions from pig houses.

Author Contributions: P.L.D.: conceptualization, methodology, formal analysis; writing-original draft preparation, writing - review and editing; A.J.A.A.: conceptualization, methodology, supervision, project administration, funding acquisition, writing-review and editing; C.M.C.v.d.P.-S.: methodology, review and editing, resources; N.W.M.O.: methodology, review and editing. All authors have read and agreed to the published version of the manuscript.

Funding: This research was funded by the Dutch Ministry of Agriculture, Nature and Food quality.

Institutional Review Board Statement: Ethical review and approval were waived for this study, due to the fact that the pigs received normal, commercially available diets and housing and management were according to Dutch law for commercial pig production. There were no interventions that required a license according to the Animal Experiments Act.

Informed Consent Statement: Not applicable.

Data Availability Statement: The data presented in this study are available on request from the corresponding author. The data are not publicly available due to data are still being processed to produce other papers.

Acknowledgments: The authors acknowledge the contribution of the people from the pig research station VIC Sterksel and from the Air Quality Lab, both from Wageningen Livestock Research.

Conflicts of Interest: The authors declare no conflict of interest. The funders had no role in the design of the study; in the collection, analyses or interpretation of data; in the writing of the manuscript, or in the decision to publish the results.

\section{References}

1. Krupa, S.V. Effects of atmospheric ammonia (NH3) on terrestrial vegetation: A review. Environ. Pollut. 2003, 124, 179-221. [CrossRef]

2. Banhazi, T.M.; Seedorf, J.; Rutley, D.L.; Pitchford, W.S. Identification of risk fac- tors for sub-optimal housing conditions in Australian piggeries: Part 2. Airborne pollutants. J. Agric. Saf. Health 2008, 14, 21-39. [CrossRef] [PubMed]

3. Galloway, J.N.; Dentener, F.J.; Capone, D.G.; Boyer, E.W.; Howarth, R.W.; Seitzinger, S.P.; Asner, G.P.; Cleveland, C.C.; Green, P.A.; Holland, E.A.; et al. Nitrogen cycles: Past, present, and future. Biogeochemistry 2004, 70, 153-226. [CrossRef]

4. Reidy, B.; Webb, J.; Misselbrook, T.H.; Menzi, H.; Luesink, H.H.; Hutchings, N.J.; Eurich-Menden, B.; Doher, H.; Dammgen, U. Comparison of models used for national agricultural ammonia emission inventories in Europe: Litter-based manure systems. Atmos. Environ. 2009, 43, 1632-1640. [CrossRef]

5. Olivier, J.G.J.; Bouwman, A.F.; Van der Hoek, K.W.; Berdowski, J.J.M. Global air emission inventories for anthropogenic sources of NOx, NH3 and N2O in 1990. Environ. Pollut. 1998, 102, 135-148. [CrossRef]

6. European Environment Agency. European Community Emission Inventory Report 1990-2008 under the UNECE Convention on Long-Range Transboundary Air Pollution; European Environment Agency: Copenhagen, Denmark, 2010.

7. Gac, A.; Beline, F.; Bioteau, T.; Maguet, K. A French inventory of gaseous emis- sions (CH4, N2O, NH3) from livestock manure management using a mass-flow approach. Livest. Prod. Sci. 2007, 112, 252-260. [CrossRef]

8. Webb, J.; Misselbrook, T.H. A mass-flow model of ammonia emissions from UK livestock production. Atmos. Environ. 2004, 38, 2163-2176. [CrossRef]

9. Cortus, E.L.; Lemay, S.P.; Barber, E.M.; Hill, G.A.; Godbout, S. A dynamic model of ammonia emission from urine puddles. Biosys. Eng. 2008, 99, 390-402. [CrossRef]

10. Le Dinh, P.; Aarnink, A. Nutritional Strategies to Reduce Emissions from Waste in Pig production. In Achieving Sustainable Production of Pig Meat; Mathew, A., Ed.; Burleigh Dodds Science Publishing: Cambridge, UK, 2019; pp. 227-242, ISBN 9781786760883.

11. CVB. PDV, Ed.; Tabellenboek Veevoeding 2012; Productschap Diervoeder: Den Haag, The Netherlands, $2012 ;$ p. 50. 
12. Lambooij, E.; Engel, B.; Buist, W.; Vereijken, P. Lean Meat Equation for the Hennessy Grading Probe (HGP7), Capteur Gras Maigre-Sydel (CGM and CSB-Image-Meater (CSB); Wageningen UR Livestock Research: Wageningen, The Netherlands, 2011 ; p. 39.

13. Schram, E.; Moore, S.; Bigwood, E.W. Chromatographic determination of cystine as cystic acid. Biochem. J. 1954, 57, 33-37. [CrossRef]

14. Sato, H.; Seino, T.; Kobayashi, T.; Murai, A.; Yugari, Y. Determination of tryptophan content of feed and feedstuffs by ion exchange liquid chromatography. Agric. Biol. Chem. 1984, 48, 2961-2969. [CrossRef]

15. Gelder, A.H.; van te Brinke, E.M.; Cone, J.W.; van Lonkhuijsen, H.J.; Jetten, J.M.; Lichtendonk, W.J. Protocol voor de Analyse van Niet-Zetmeel Koolhydraten (Protocol for Analysing Non-Starch Polysaccharides); Kwaliteitsreeks nr. 19; Productschap voor Veevoeder: The Hague, The Netherlands, 1992.

16. Ogink, N.W.M.; Mosquera, J.; Hol, J.M.G. Protocol voor meting van ammoniakemissie uit huisvestingssystemen in de veehouderij. Livest. Res. 2013, 621, 523976.

17. Mosquera, J.; Hofschreuder, P.; Erisman, J.W.; Mulder, E.; Van 't Klooster, C.E.; Ogink, N.; Swierstra, D.; Verdoes, N. Meetmethoden Gasvormige Emissies uit de Veehouderij; Instituut voor Milieu- en Agritechniek, Rapport 2002-12: Wageningen, The Netherlands, 2002; p. 247.

18. Derikx, P.J.L.; Willers, H.C.; Ten Have, P.J.W. Effect of $\mathrm{pH}$ on behaviour of volatile compounds in organic manures during dry-matter determination. Bioresour. Technol. 1994, 49, 41-45. [CrossRef]

19. Hafner, S.; Bisogni, J.J. A Simple Method for Measurement of Inorganic Carbon Concentration and Carbonate System Alkalinity in Anaerobic Digesters. Agric. Eng. Int. CIGR J. 2007, IX, 1-15.

20. Bakker, G.C.M.; Hol, J.M.G.; Smits, M.C.J.; Jongbloed, A.W. The Additivity of Feeding Measures to Reduce Ammonia Emission from Pig Houses; 2. Ammonia Emission Measurements at Housing Level and In Vitro for Three Different Diets; Animal Sciences Group: Wageningen, The Netherlands; Lelystad, The Netherlands, 2005; p. 36.

21. Aarnink, A.J.A. Ammonia Emission from Houses for Growing Pigs as Affected by Pen Design, Indoor Climate and Behaviour; Agricultural University Wageningen: Wageningen, The Netherlands, 1997.

22. Canh, T.T.; Aarnink, A.J.A.; Mroz, Z.; Jongbloed, A.W. Influence of dietary calcium salts and electrolyte balance on urinary pH, slurry $\mathrm{pH}$ and ammonia volatilisation from slurry of growing finishing pigs. J. Anim Sci. 1997, 75 (Suppl. 1), 1989.

23. Canh, T.T.; Aarnink, A.J.A.; Mroz, Z.; Jongbloed, A.W.; Schrama, J.W.; Verstegen, M.W.A. Influences of electrolyte balance and acidifying calcium salts in the diet of growing-finishing pigs on urinary $\mathrm{pH}$, slurry $\mathrm{pH}$ and ammonia volatilisation from slurry. Livest. Prod. Sci. 1998, 56, 1-13. [CrossRef]

24. Canh, T.T.; Aarnink, A.J.A.; Schutte, J.B.; Sutton, A.; Langhout, D.J.; Verstegen, M.W.A. Dietary protein affects nitrogen excretion and ammonia emission from slurry of growing-finishing pigs. Livest. Prod. Sci. 1998, 56, 181-191. [CrossRef]

25. Canh, T.T.; Aarnink, A.J.A.; Verstegen, M.W.A.; Schrama, J.W. Influences of dietary factors on the $\mathrm{pH}$ and ammonia emissions of slurry from growing-finishing pigs. J. Anim Sci. 1998, 76, 1123-1130. [CrossRef] [PubMed]

26. Hernández, F.; Martínez, S.; López, C.; Megías, M.; López, M.; Madrid, J. Effect of dietary crude protein levels in a commercial range, on the nitrogen balance, ammonia emission and pollutant characteristics of slurry in fattening pigs. Animal 2011, 5 , 1290-1298. [CrossRef]

27. Le, P.D.; Aarnink, A.J.A.; Jongbloed, A.W. Odour and ammonia emission from pig manure as affected by dietary crude protein level. Livest. Sci. 2009, 121, 267-274. [CrossRef]

28. Le, P.D.; Aarnink, A.J.A.; Jongbloed, A.W.; van de Peet-Schwering, C.M.C.; Verstegen, M.W.A.; Ogink, N.W.M. Effects of dietary crude protein level on odor from pig manure. Animal 2007, 1, 734-744. [CrossRef]

29. United Nations Economic Commission for Europe. Framework Code for Good Agricultural Practice for Reducing Ammonia Emissions; United Nations Economic Commission for Europe: Geneva, Switzerland, 2015; p. 31.

30. Nørgaard, J.V.; Hansen, M.J.; Soumeh, E.A.; Adamsen, A.P.S.; Poulsen, H.D. Effect of protein level on performance, nitrogen utilisation and carcass composition in finisher pigs. Acta. Agric. Scand. Anim. Sci. 2014, 64, 123-129. [CrossRef]

31. O'Connell, J.M.; Callan, J.J.; O'Doherty, J.V. The effect of dietary crude protein level, cereal type and exogenous enzyme supplementation on nutrient digestibility, nitrogen excretion, faecal volatile fatty acid concentration and ammonia emissions from pigs. Anim. Feed Sci. Technol. 2006, 127, 73-88. [CrossRef]

32. Cromwell, G.L.; Coffey, R.D. Future strategies to dinimish nitrogen and phosphorous in swine manure. Meeting the Environmental Challange. In Proceedings of NPPC Environmental Symposium; NPPC: Ames, IA, USA; Minneapolis, NN, USA, 1993.

33. Jongbloed, A.W.; Lenis, N.P. Excretion of nitrogen and some minerals by livestock. In Nitrogen Flow in Pig Production and Environmental Consequences; Verstegen, M.W.A., den Hartog, L.A., van Kempen, van Metz, G.J.M., Eds.; EAAP Pub No. 69 Pudoc Scientific Publishers: Wageningen, The Netherlands, 1993; pp. 22-36.

34. Portejoie, S.; Dourmad, J.-Y.; Martinez, J.; Lebreton, Y. Effect of lowering dietary crude protein on nitrogen excretion, manure composition and ammonia emission from fattening pigs. Livest. Prod. Sci. 2004, 91, 45-55. [CrossRef]

35. Aarnink, A.J.A.; Verstegen, M.W.A. Nutrition, key factor to reduce environmental load from pig production. Livest. Sci. 2007, 109, 194-203. [CrossRef]

36. Shriver, J.A.; Carter, S.D.; Sutton, A.L.; Richert, B.T.; Senne, B.W.; Pettey, L.A. Effects of adding fiber sources to reduced-crude protein, amino acid-supplemented diets on nitrogen excretion, growth performance, and carcass traits of finishing pigs. J. Anim. Sci. 2003, 81, 492-502. [CrossRef] [PubMed] 
37. Madrid, J.; Martínez, S.; López, C.; Orengo, J.; López, M.J.; Hernández, F. Effects of low protein diets on growth performance, carcass traits and ammonia emission of barrows and gilts. Anim. Prod. Sci. 2013, 53, 146-153. [CrossRef]

38. Hansen, M.J.; Nørgaard, J.V.; Adamsen, A.P.S.; Poulsen, H.D. Effect of reduced crude protein on ammonia, methane, and chemical odorants emitted from pig houses. Livest. Sci. 2014, 169, 118-124. [CrossRef]

39. Kay, R.M.; Lee, P.A. Ammonia emission from pig buildings and characteristics of slurry produced by pigs offered low crude protein diets. In International Symposium on Ammonia and Odour Control from Animal Production Facilities; Voermans, J.A.M., Monteny, G.J., Eds.; NVTL: Rosmalen, The Netherlands; Vinkeloord, The Netherlands, 1997; pp. 253-259.

40. Aarnink, A.J.A.; Hoeksma, P.; Ouwerkerk, E.N.J. Factors affecting ammonium concentration in slurry from fattening pigs. In Nitrogen Flow in Pig Production and Environmental Consequences; Verstegen, M.W.A., den Hartog, L.A., van Kempen, G.J.M., Eds.; EAAP Pub No. 69 Pudoc Scientific Publishers: Wageningen, The Netherlands, 1993; pp. 413-420.

41. Bühler, K.; Wenk, C.; Broz, J.; Gebert, S. Influence of benzoic acid and dietary protein level on performance, nitrogen metabolism and urinary $\mathrm{pH}$ in growing-finishing pigs. Arch. Anim. Nutr. 2007, 60, 382-389. [CrossRef] [PubMed]

42. Kluge, H.; Broz, J.; Eder, K. Effects of dietary benzoic acid on urinary $\mathrm{pH}$ and nutrient digestibility in lactating sows. Livest. Sci. 2010, 134, 119-121. [CrossRef]

43. Daumerm, M.-L.; Guiziou, F.; Dourmard, J.-Y. Influence de la teneur en protéines de l'aliment et de l'addition d'acide benzoique et de phytase microbienne sur les caractéristiques des effluents chez le porc à l'engraissement. Journées Rech. Porc. 2007, 39, 13-22.

44. Kim, I.B.; Ferket, P.R.; Powers, W.J.; Stein, H.H.; Van Kempen, T.A.T.G. Effects of different dietary acidifier sources of calcium and phosphorus on ammonia, methane and odorant emission from growing-finishing pigs. Asian Australas J. Anim. Sci. 2004, 17, 1131-1138. [CrossRef]

45. Hansen, C.F.; Sørensen, G.; Lyngbye, M. Reduced diet crude protein level, benzoic acid and inulin reduced ammonia, but failed to influence odour emission from finishing pigs. Livest. Sci. 2007, 109, 228-231. [CrossRef]

46. den Brok, G.M.; Hendriks, J.G.L.; Vrielink, M.G.M.; van der Peet-Schwering, C.M.C. Urinary pH, Ammonia Emission and Performance of Growing/Finishing Pigs after the Addition of a Mixture of Organic Acids, Mainly Benzoic Acid, to the Feed; Experimental Farm for Pig Husbandry: Raalte, The Netherlands, 1999; p. 35.

47. Oldenburg, J.; Heinrichs, P. Quantitative Aspecte einer proteinreduzierten Schweinemast. Lohamann Inf. 1996, 1, $13-16$.

48. Lopez, J.; Goodband, R.D.; Allee, G.L.; Jesse, G.W.; Nelssen, J.L.; Tokach, M.D.; Spiers, D.; Becker, B.A. The effects of diets formulated on an ideal protein basis on growth performance, carcass characteristics, and thermal balance of finishing gilts housed in a hot, diurnal environment. J. Anim Sci. 1994, 72, 367-379. [CrossRef] [PubMed]

49. Hahn, J.D.; Biehl, R.R.; Baker, D.H. Ideal digestible lysine level for early- and late-finishing swine. J. Anim Sci. 1995, 73, 773-784. [CrossRef] 